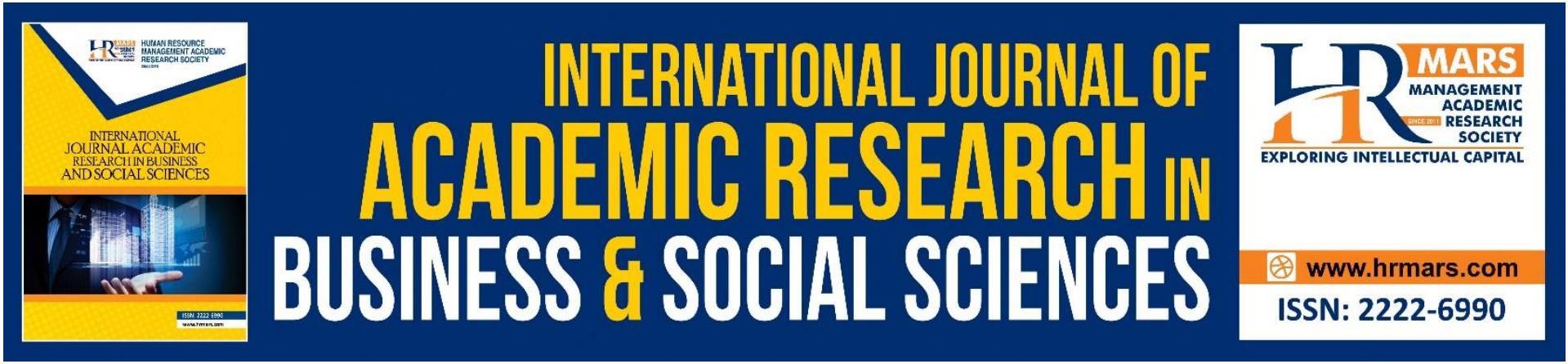

\title{
Nursing Students' Perception on Mentoring Program in Improving Students' Academic Achievement
}

Rusnani Ab Latif, Wan Ismahanisa Ismail, Siti Munirah Abdul Wahab, Muhammad Amin Ahmad Zaki, Mazriyana Md Kasim, Norasma Bakar

To Link this Article: http://dx.doi.org/10.6007/IJARBSS/v11-i10/11510～DOI:10.6007/IJARBSS/v11-i10/11510

Received: 12 August 2021, Revised: 10 September 2021, Accepted: 28 September 2021

Published Online: 24 October 2021

In-Text Citation: (Latif et al., 2021)

To Cite this Article: Latif, R. A., Ismail, W. I., Wahab, S. M. A., Zaki, M. A. A., Kasim, M. M., \& Bakar, N. (2021). Nursing Students' Perception on Mentoring Program in Improving Students' Academic Achievement. International Journal of Academic Research in Business and Social Sciences, 11(10), 1277 - 1293.

Copyright: @ 2021 The Author(s)

Published by Human Resource Management Academic Research Society (www.hrmars.com)

This article is published under the Creative Commons Attribution (CC BY 4.0) license. Anyone may reproduce, distribute, translate and create derivative works of this article (for both commercial and non-commercial purposes), subject to full attribution to the original publication and authors. The full terms of this license may be seen at: http://creativecommons.org/licences/by/4.0/legalcode

Vol. 11, No. 10, 2021, Pg. $1277-1293$

Full Terms \& Conditions of access and use can be found at http://hrmars.com/index.php/pages/detail/publication-ethics 


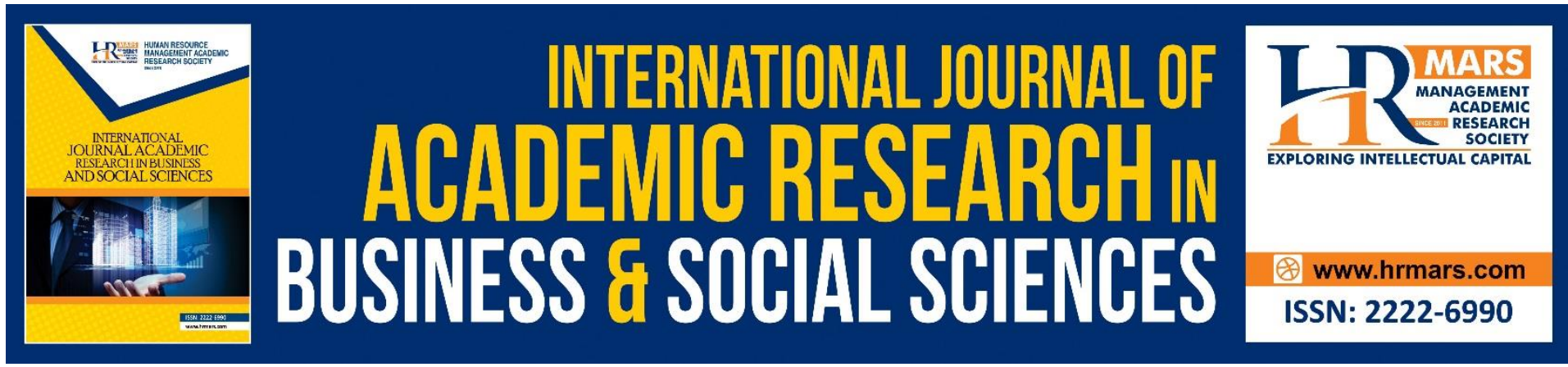

\title{
Nursing Students' Perception on Mentoring Program in Improving Students' Academic Achievement
}

\author{
Rusnani Ab Latif, Wan Ismahanisa Ismail, Siti Munirah \\ Abdul Wahab, Muhammad Amin Ahmad Zaki, Mazriyana \\ Md Kasim, Norasma Bakar \\ Faculty of Health Sciences, Universiti Teknologi MARA, Cawangan Pulau Pinang, \\ Kampus Bertam, 13200, Kepala Batas, Pulau Pinang. Malaysia.
}

\begin{abstract}
In Malaysia, mentoring program have been widely implemented in a number of higher education institutions and schools. As a result, implementing this mentoring programs can be one of the learning approaches for students who want to improve their academic performance. This study aim to explore the nursing students' perception on mentoring program at ILKKM Kubang Kerian, Kelantan. This is a descriptive cross-sectional study. This study involved 46 students who were selected by purposive sampling. The assessments are made up of 6 sections such as students background, communication, support, self-efficacy, psychosocial and academic achievement. All items used in the questionnaires were measured based on 7- item Likert scale ranging from 1-strongly disagree to 7-strongly agree. The data was analyzed by using Statistical Package for Social Science (SPSS) version 24.0 Descriptive analysis was done for the frequency, percentage, the mean and standard deviation. The results of the study found that all respondents agreed $100 \%$ that the mentoring program can improve the level of communication and academic performance. To put it another way, the results of this study showed that implementing this mentee mentoring programs improved nursing students communication skills and academic achievement. To put it another way, the findings of this study demonstrated that establishing mentoring programs increased the communication skills and academic achievement of nursing students. As a result, further study on mentoring programs for nursing students is needed to provide direction and references. The findings of this study may seek to set this mentoring program as a more effective learning strategy for nursing students who want to enhance their academic achievements. It has the potential to impart knowledge and increase the nursing student's existing knowledge in an indirect manner. These positive impacts could contribute to improved performance of higher learning institutions in a particular field of study.
\end{abstract}

Keywords: Mentoring Program, Nursing Students, Academic Achievement 


\section{Introduction}

An efficient learning technique helps students to achieve excellence in their academic field. The mentee mentoring programmer was widely implemented in several institutions of higher learning and schools in Malaysia. Mentoring programs are often seen as a crucial teaching and learning method in higher education institutions (Scandura \& Williams, 2004). According to Oliver and Aggleto (2002), the implementation of a planned mentoring mentor programs can make more knowledgeable, skilled and new ability to enhance performance in the academic field. The mentor gives a description of something that has been designed, means teaching how to use a technique or tool, encourages discussion among members, and tests mentee understanding with specific problem-solving techniques in a formal mentoring programs (Hills \& Jones, 1998; Kaye, 1997; MacGregor, 2000; Ragins, 1999). Hence, the implementation of the mentor-mentee programmer can be one of the learning methods for students in enhancing their academic achievements. Through this mentor-mentee program, students can create a closer relationship with the instructor where students can communicate directly or indirectly with their instructors.

The communication between these two parties can increase the confidence of the students to be braver to ask the instructor related to their academic matter. It was supported by Azman et al. (2007) which reported the mentoring method of learning to enhance the practice of communication between educators and students (mentee) which involves the process of transferring knowledge and skills to students. According to Rethu \& Ganesh (2012), the mentoring program is able to train in knowledge development, enhancement and learning new skills, positive attitude, and current demands so that they may improve competition and handle difficulties in both internal and external environments in a cautious manner.

The academic adviser mentorship programs is also an interactive approach combining students and academic advisors with the goal of advancing students through educational programs at the proper moment. According to Yuko and Amy (2017), an academic advisor's role is to work behind the scenes to help students succeed academically. This demonstrates the importance of mentors in the development of self-efficacy and mentee confidence. Through communication and engagement between nurse educators and nursing students, this study is able to demonstrate the usefulness of a mentoring program in enhancing nursing students' academic achievement. A designated instructor will give guidance to a group of students who are entrusted with their responsibilities. Despite the fact that every student has an advisor, some are unaware of the purpose and function of such academic advisors. During the semester, a meeting between nurse educators and nursing students will be held, with the frequency of the meeting would be at least twice every semester between the nurse educators and nursing students. Sequence from that, this study was undertaken with the goal of exploring nursing students' perceptions of mentoring programs in terms of improving academic achievement, with the findings potentially being utilized to improve nursing students' learning methods through mentoring programs.

According to the Malaysian Ministry of Education's mentee mentoring program's goal of raising awareness and interest in studying in order to overcome students' weaknesses. This is because students need continuous guidance especially in institutions of higher learning (IPT). According to Bryne and Keefe (2012), mentee mentoring programs is an excellent technique for all domains, including health, because it is one of the skills, expertise, and leadership development programs. To become a competent and knowledgeable nursing student, excellent academic achievement needs to be achieved to equip themselves with all 
the knowledge to be practiced in clinical and theoretical classes. Among the problems faced by nursing students to achieve academic excellence are lacking in attention during class sessions. This can cause their academic results to deteriorate due to lack of focus and understanding in education.

In addition, problems such as nursing students are studying at the end of the examination as well as academic causes to deteriorate due to lack of mental and physical preparations to cope with the examination. The mentor will always remind and assist the nursing students to prepare early preparations before the examination. Stress is also a major factor in the academic decline. The nursing students suffered from the field of nursing education and was afraid of failing a diploma in nursing course. With a mentor or instructor with them, they can express their hearts and strive to tackle the stress faced together. As a result, the aim of this study is to find out how nursing students at ILKKM Kubang Kerian perceive mentorship programs in terms of improving their academic performance. The outcome of this study may be able to make this mentoring program as an initiative as a more effective learning technique for nursing students to enhance academic achievements.

\section{Literature Review}

\section{Student Perception of Mentoring Program in Academic Achievement}

The mentor-mentee in defining as a process in which an experienced individual acts as a counsellor, counselor, tutor or coach to an inexperienced individual in a particular field (Rethu \& Ganesh, 2012; Azman et al., 2013). The main focus of the programed is to train and the development of mentee especially in the field of careers and psychosocial mentee such as essential knowledge, current skills, new abilities, positive attitude and current needs so that they are able to enhance self-competitiveness, manage opportunities and problems prudently, and respond to various challenges in the internal and external environment of the organization (Rethu \& Ganesh, 2012).

The mentor-mentee program can change the environment of learning and the program is seen as one of the best steps to ensure good academic achievement can be achieved. According to the Sulong \& Yusof (2010), greed that the needs of this mentormentee programed can help students adapt to the academic and the university environment. In the context of the organization, there are many studies conducted by researchers who have brought the mentoring to have a positive impact on mentee (e.g. career and psychosocial fields) and organization (Ghosh \& Jr, 2013; Wang et al., 2010; Chen et al., 2014).

According to Byrne and Keefe (2002), mentee mentoring program is an effective strategy for all fields including the health field, this is because it is one of the skills, expertise and leadership development programs. In addition, the mentor-mentee program guides individuals in addressing psychosocial problems (Ljungberg et al., 2011). The result showed that the mentor-mentee programed was used by all fields in assisting individual development. Very surprisingly, when the study was implemented recently that the mentor capability in practicing the characteristics of the mentor would have a positive impact on the mentee, particularly the self-ability of mentee (Ismail \& Ridzwan, 2012, 2015; Rayle et al., 2006) and psychosocial mentee (Allen \& Finkelstein, 2003; Dutton, 2003; Ismail \& Khian Jui, 2013; Ismail et al., 2015). 


\section{Methodology}

\section{Study Population}

This is a descriptive cross-sectional study. The population of the study involved nursing students at the ILKKM Kubang Kerian (Nursing), which consists of year 2 nursing students, namely semester 3 a total of 22 people and semester 4 a total of 24 people. This brings the total number of nursing students involved to 46 people. The sampling technique used in this study is purposive sampling, where the researchers choosing the respondents of the population to participate in this study.

\section{Inclusion Criteria}

The criteria selected are the nursing students of 2 Semester I and 2 Semester II and volunteer to be the respondents.

\section{Exclusion Criteria}

Year 1 nursing students (Semester I and II), Year 3 (Semester V and 3 VI) ; Nursing students who are sick leave during the collection of data are made; Nursing students withdrawing during data collection are done.

\section{Instrument Tool}

The instrument used is a questionnaire that includes six sections, namely part $A, B, C, D, E, F$ to obtain data. The questionnaire used was adapted from Azman Ismail(2013), all items used in the questionnaires were measured based on 7-item Likert scale ranging from 1-strongly disagree(SA), 2- Disagree(D),3- Slightly Disagree(SD),4- Not Sure(NT),5- Slightly Agree(SA),6Agree(A) to 7- strongly agree(SA) except for part A(sociodemographic data).

\section{Part A}

Part A contains the demographic information of the respondent, which includes age, education level, year of study, CGPA and interest in nursing. This item is presented as a closed question.

\section{Part B}

This section contains of 4 questions aimed at knowing the communication between mentoring in delivering information to mentee through explanation, discussion and sharing knowledge on nonacademic and academic matters.

\section{Part C}

This section contains 10 questions of support of mentoring against mentee to attend the mentoring programed to praise mentee when he gained good results in his studies and was willing to provide assistance for mentee who had difficulties in learning.

\section{Part D}

This section contains 2 main questions, which question 1 have 4 sub questions and question 2 have $s$ sub questions of the self-efficacy refers to the mentee (student) believe and confident with the implementation of mentoring programs. 


\section{Section E}

This section contains 1 main question that divided to 8 sub questions and assesses the psychosocial mentee to establish and maintain good relationship with friends, instructors and institutional staff and are able to adapt to the conditions of the institution life.

\section{Part F}

This section contains 1 main question that divided to 8 sub questions. This division evaluates the academic achievement of mentee to achieve good academic results. Academic performance refers to the mentee's (student's) ability to achieve good academic results such as scoring good grades for courses taken, obtaining high CGPA, and producing good assignment reports.

\section{Data Collection}

Questionnaires were distributed to nursing students in the form of questionnaire. The nursing students are required to answer the questionnaire. This form of questionnaires consists of six sections. Once the respondent is done to answer all the questions given, the collection of data is done and all information obtained is confidential as it is intended for academic information.

\section{Data Analysis}

Data collection is done in detail on selected respondents through questionnaires. To know the entire questionnaire form is collected. The SPSS version 24.0 Program is used to analyses data. The analysis of such data contains percentages, averages, mean and standard deviation to provide a clearer understanding of the results of the study performed.

\section{Result}

\section{Background of Sociodemographic}

This section reports demographic information analysis which consists of age, education level, Year of study academic achievement and interest in nursing field. The mean age of respondents was $21.9(\mathrm{SD}=1.96)$ which ranged from $20-22$ years old $32(69.6 \%)$ and from 2325 was 14(30.4\%). The peak age was among students of 20 years old category $11(23.9 \%)$. Majority of the educational level of respondents were SPM level $23(50.0 \%)$, followed by diploma $(16,34.8 \%)$, STPM level was $3(6.5 \%)$ and $4(8.7 \%)$ nursing students have level of education at the matriculation level. Subsequently, the respondent from Year 2 Semester 1 was 22(47.8\%) and 24(52.2\%) from Year 2 Semester II. For the academic achievements, more than half of the students achieve CGPA between 3.51 and 4.00 (69.6\%). The mean of CGPA was 3.59. Most of the nursing students interest in nursing $(58.7 \%)$. The analysis of the study is shown in Table 1. 
Table 1: Background sociodemographic nurse Diploma in Nursing $(n=46)$

\begin{tabular}{|c|c|c|c|}
\hline Variables & $\mathrm{N}$ & $\%$ & Mean \pm SD \\
\hline Age & & & $21.9 \pm 1.96$ \\
\hline $20-22$ & 32 & 69.6 & \\
\hline $23-25$ & 14 & 30.4 & \\
\hline \multicolumn{4}{|l|}{ Educational level } \\
\hline SPM & 23 & 50.0 & \\
\hline STPM & 3 & 6.5 & \\
\hline Diploma/Degree & 16 & 34.8 & \\
\hline Matriculation & 4 & 8.7 & \\
\hline \multicolumn{4}{|l|}{ Year of study } \\
\hline (Year 2 semester I) & 22 & 47.8 & \\
\hline (Year 2 semester II) & 24 & 52.2 & \\
\hline CGPA & & & $3.59 \pm 0.72$ \\
\hline $2.00-250$ & 1 & 2.2 & \\
\hline $2.51-3.00$ & 3 & 6.5 & \\
\hline $3.01-3.50$ & 10 & 21.7 & \\
\hline $3.51-4.00$ & 32 & 69.6 & \\
\hline \multicolumn{4}{|l|}{ Interest in nursing } \\
\hline Yes & 27 & 58.7 & \\
\hline No & 19 & 41.3 & \\
\hline
\end{tabular}

Communication(The communication between mentoring (lecturers) delivers information to mentee (trainees) through explanation, discussion and sharing knowledge on nonacademic and academic matters\}.

Table 2 reveals that Item 1 to 4 based on 7 point Likert scale regarding the communication between mentoring (lecturers) delivers information to mentee (trainees) through explanation, discussion and sharing knowledge on non-academic and academic matters. The total score were converted into percentages. The highest agreeing percentage is item 3 (Useful information can be delivered through face to face communication), about 29 (63.0\%) were agree and 13 (28.3\%) were totally agree. The lowest percentage is item 4(open communication in mentoring program can help me to think critically) shows that $9(19.6 \%)$ were somewhat agreed, 30 (65.2\%) were agreed and 7 (15.2\%) were totally agree. However, the overall agree percentage is $100 \%$. 
Table 2: Students' perceptions toward communication in mentoring program( $n=46)$.

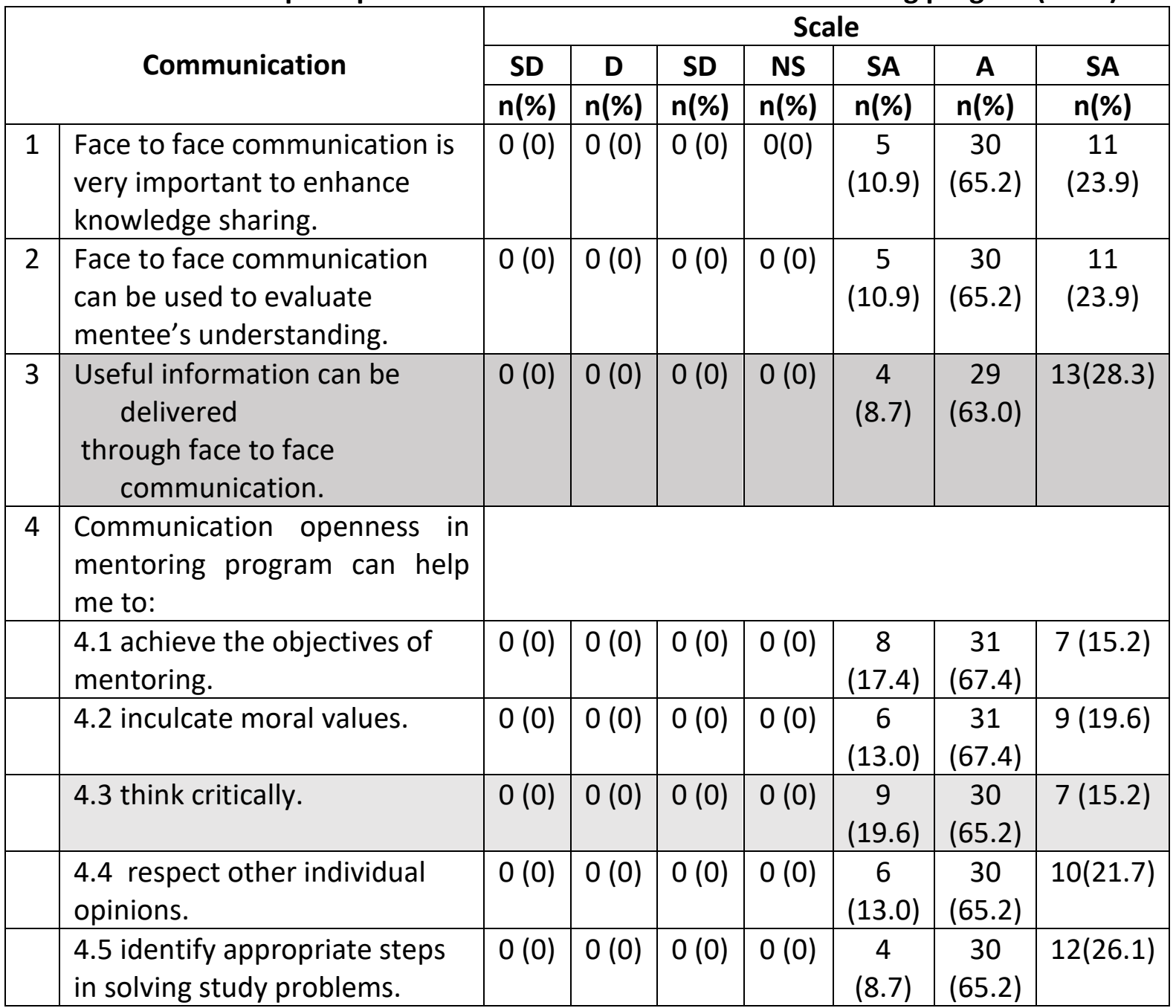

Support( support is the mentor of pushing mentee to attend mentoring program, praise mentee when he gets good results and is willing to give aid to the mentee that faces hardship in learning).

Table 3 reveals that Item 1 to 7 regarding the support( support is the mentor of pushing mentee to attend mentoring program, praise mentee when he gets good results and is willing to give aid to the mentee that faces hardship in learning). The highest agreeing percentage is item 3(my mentor motivates me to improve my interpersonal communication skills), where a total of $10(21.7 \%)$ were somewhat agreed, a total of 24 (52.2\%) were agreed and a total of 11 (23.9\%) were very agreed. Also for item 4 (my mentor always gives me positive comments), where only $1(2.2 \%)$ of the respondents stated not sure, while a total of $9(19.6 \%)$ were somewhat agreed, a total of 25 (54.3\%) were agreed and a total of 11 (23.9\%) were very agreed. The lowest percentage is item 9 (my mentor always listens to my problems) while a total of $12(26.1 \%)$ were somewhat agreed, a total of 21 (45.7\%) were agreed and a total of $10(21.7 \%)$ were very agreed. However, the overall agree percentage is $65.21 \%$. 
Table 3: Students' perceptions toward support in mentoring program $(n=46)$.

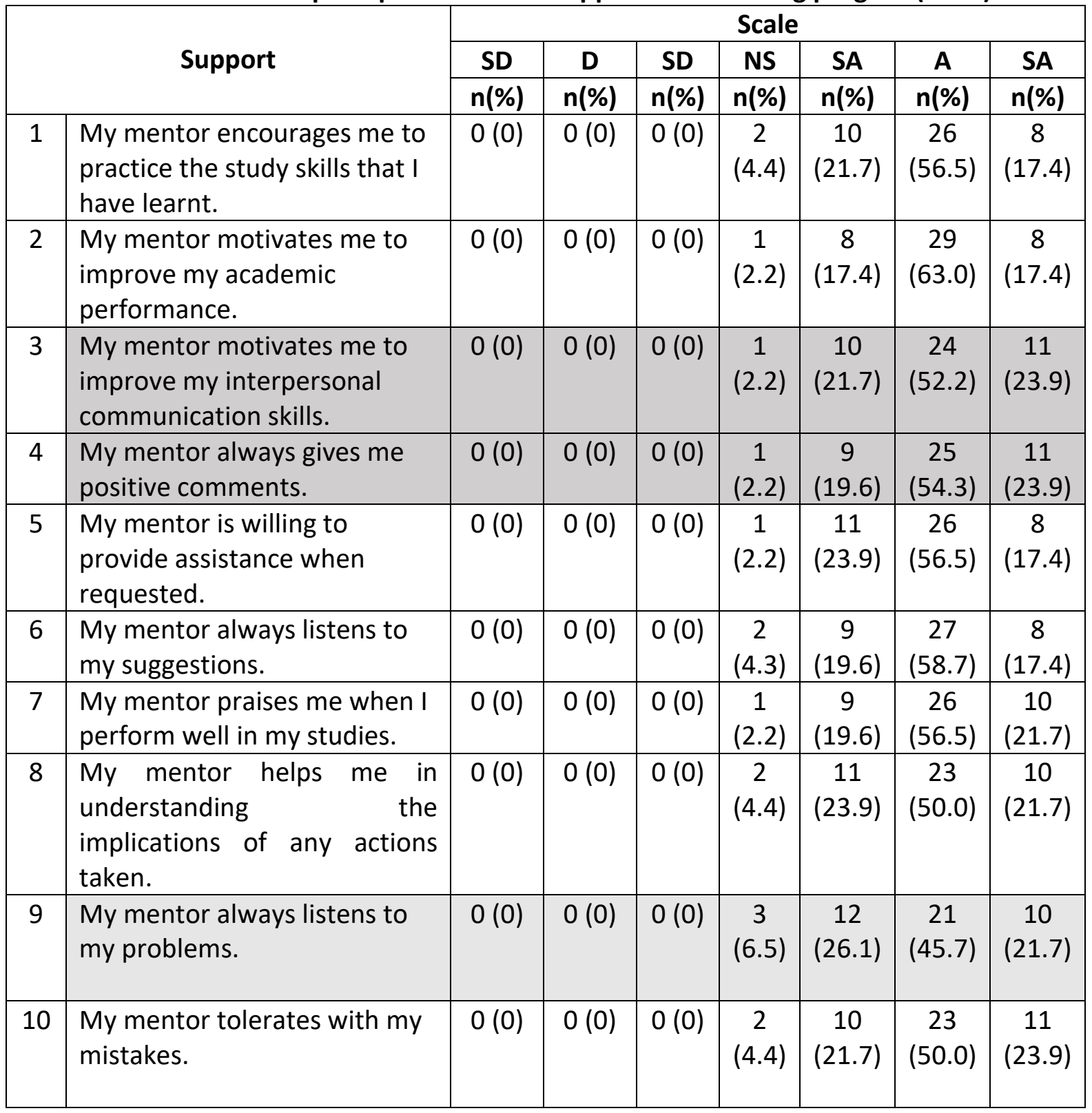

Self-efficiency (Self-efficiency means mentee (students) believe and be confident with the implementation of mentoring program).

Table 4 reveals that the self-efficiency (self-efficiency means mentee (students) believe and be confident with the implementation of mentee mentoring program). The highest agreeing percentage is item 1 (I believe that the mentor-mentee program helps me to adapting myself in learning), where a total of $10(21.74 \%)$ respondents were somewhat agreed, $24(52.17 \%)$ were agreed and 12 (26.09\%) were strongly agree. The lowest percentage is item 1 (I believe that mentoring programs can help me in managing failure), were 2 (4.3\%) respondents were uncertain, 12 (26.1\%) were somewhat agreed, 23 (50.0\%) were agreed and 9 (19.6\%) were strongly agree. However, the overall agree percentage is $80.43 \%$. 
Table 4: Students' perceptions toward self-efficacy in mentoring program( $n=46)$.

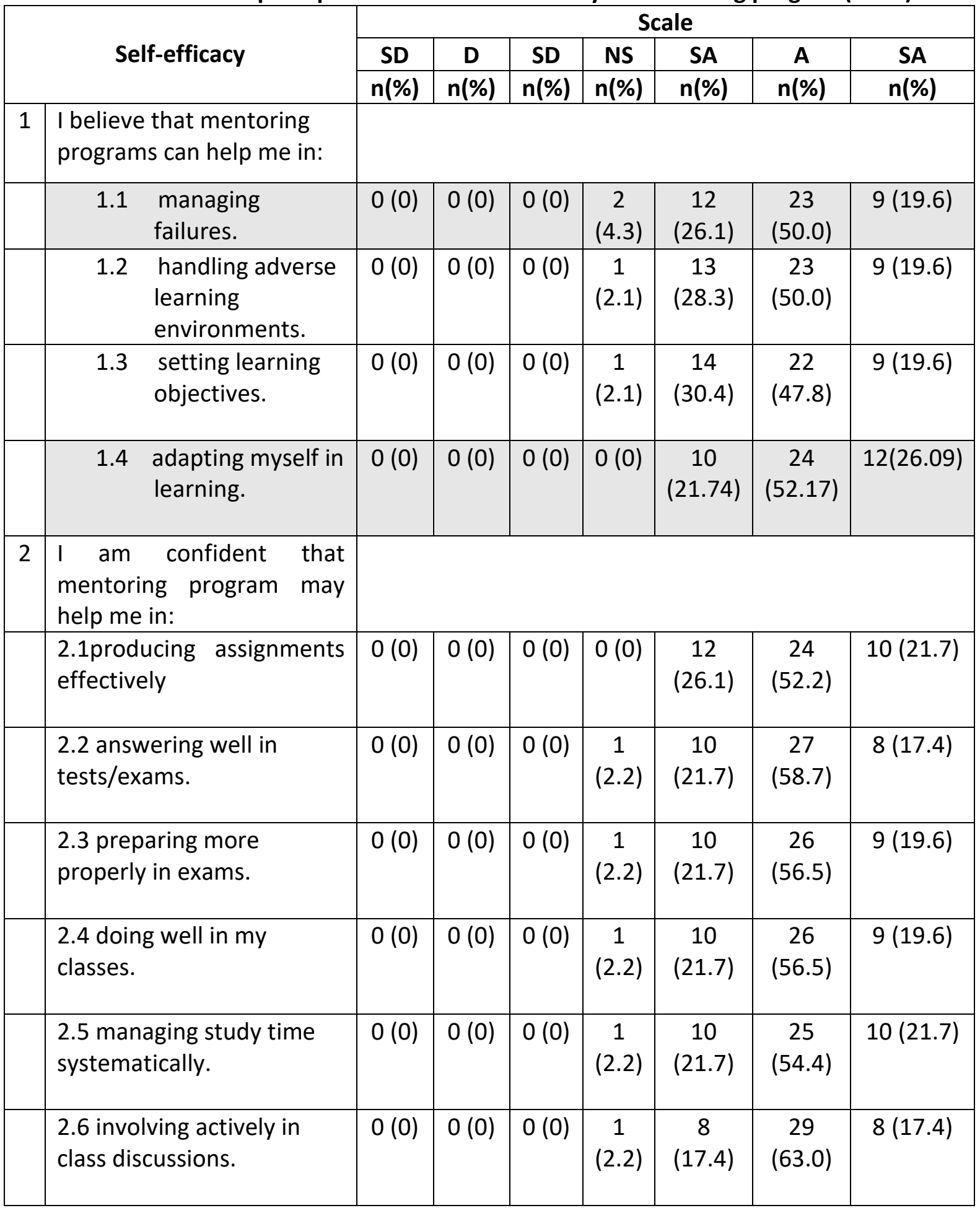

Psychosocial(psychosocial means mentee (students) are able to forge and maintain good relationship with friends, lecturers and college staff, and are able to adapt to the state of college life).

Table 5 reveals that the psychosocial(psychosocial means mentee (students) are able to forge and maintain good relationship with friends, lecturers and college staff, and are able to adapt to the state of college life). The highest agreeing percentage is item 1 ( $\mathrm{l}$ am able to meet new students), a total of $10(21.7 \%)$ respondents were somewhat agreed, 27 (58.7\%) were agreed 
and $9(19.6 \%)$ were very agreed. The lowest percentage is item 1 (share my personal experiences with other individuals), where a total of $2(4.35 \%)$ respondents were uncertain, $13(28.26 \%)$ were somewhat agreed, 25 (54.35\%) were agreed and 6 (13.04\%) were very agreed. However, the overall agree percentage is $91.30 \%$.

Table 5: Students' perceptions toward psychosocial in mentoring program ( $n=46)$.

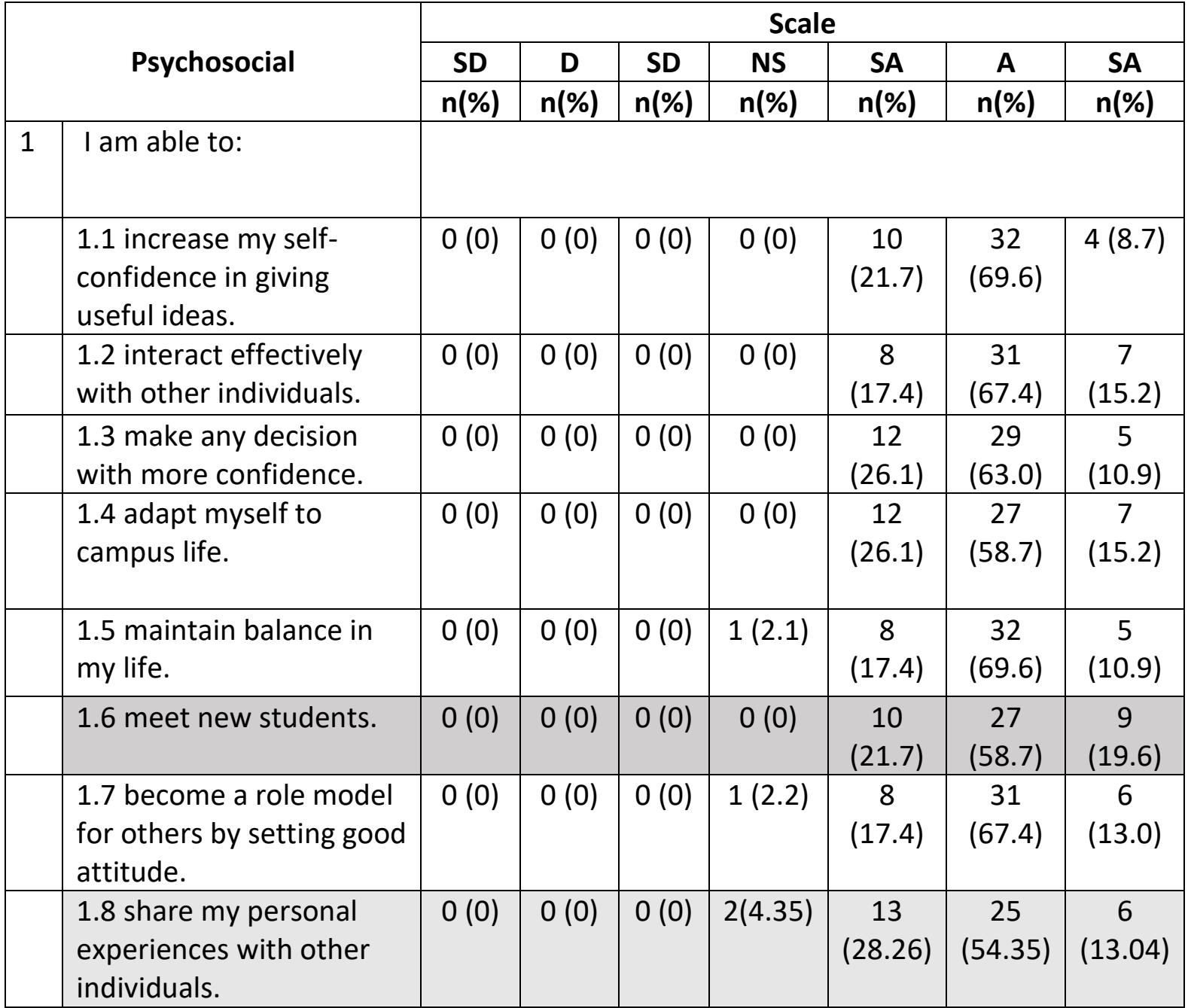

Academic achievement(Academic achievements mean the mentee (students) are able to achieve good academic results such as good results in the subjects taken, achieving a high CGPA and a report of good assignments).

Table 6 reveals that the academic achievement (academic achievements mean the mentee (students) are able to achieve good academic results such as good results in the subjects taken, achieving a high CGPA and a report of good assignments). The highest agreeing percentage is item 1 ( $\mathrm{I}$ am able to perform any responsibility to be a good student), a total of 28(60.9\%) were agreed and 18 (39.1\%) were very agreed. The lowest percentage is item 1(1 am able to accomplish an tasks on time), a total of 9 (19.6\%) respondents were somewhat agreed, 27 (58.7\%) were agreed and 10 (21.7\%) were very agreed. However, the overall agree percentage is $100 \%$. 
INTERNATIONAL JOURNAL OF ACADEMIC RESEARCH IN BUSINESS AND SOCIAL SCIENCES Vol. 11 , No. 10, 2021, E-ISSN: 2222-6990 ๑ 2021 HRMARS

Table 6: Students' perceptions toward academic performance in mentoring program $(n=46)$.

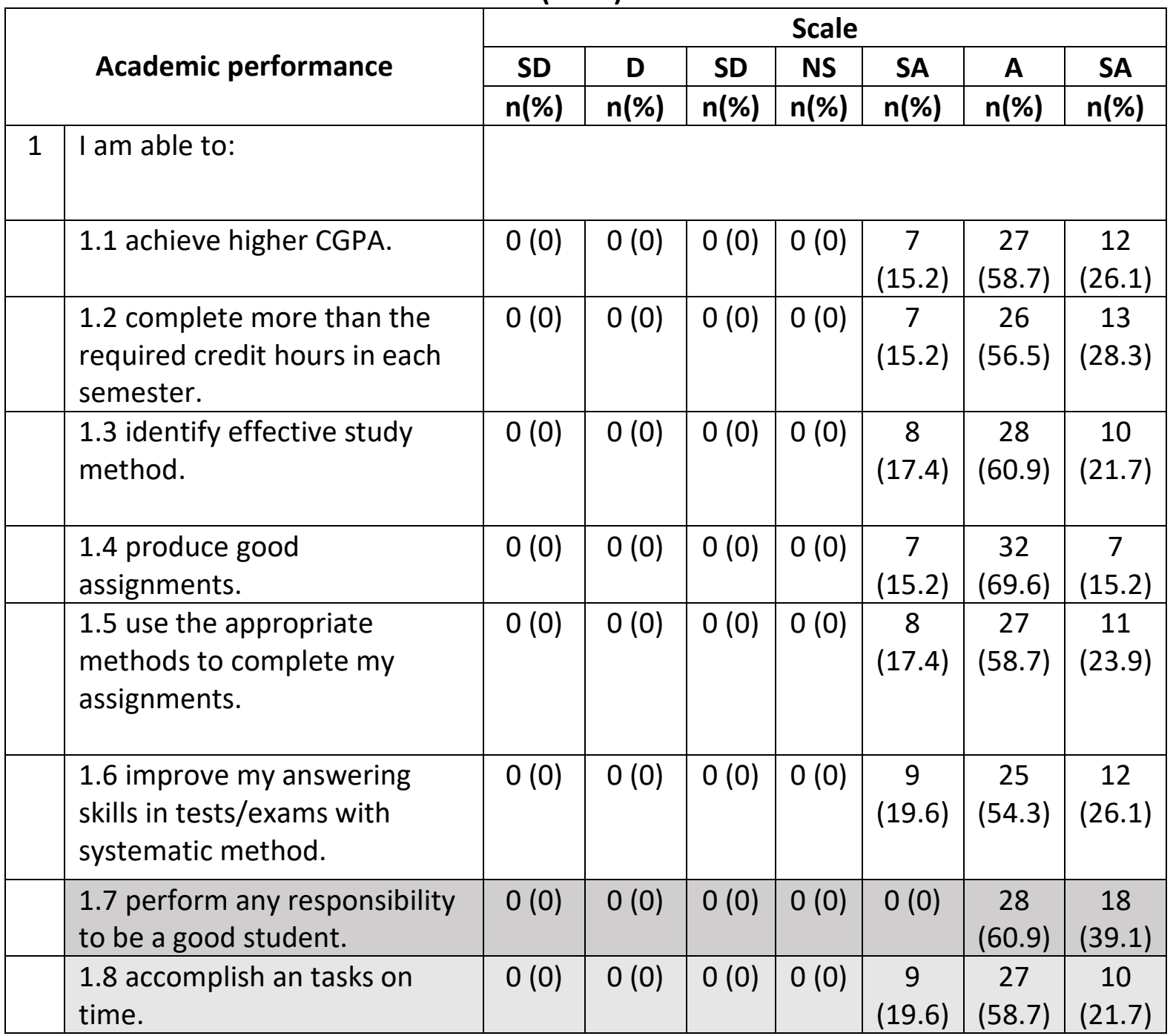

\section{Discussion}

The perception of nursing students on the implementation of the mentee mentoring programs at the ILKKM Kubang Kerian (Nursing).

\section{Communication}

The results of the study show $100 \%$ of the respondents agree that mentoring program increased their communication. The results in communication elements showed most of respondents were agreed that useful information can be communicated through a face-facing communication between mentoring and mentee and can identify appropriate steps in solving study problems. According to Eller (2014), communication practices in the mentoring programmer are able to enhance their confidence, skills and motivate the mentee to do their own development. It is also supported by Azman (2007) stated that this method of learning has increased the practice of communication between trainers and students (mentee) where the communication practices have managed to move the knowledge, skills and ability to students. The capability of mentors and mentees to implement effective communication in mentoring program may have a significant impact on mentees' outcomes, especially study performance (Ismail et al., 2016; Ismail et al., 2012; Santos \& Reigadas, 2005). Sarwari et al. 
(2016) highlighted that the interpersonal of communication is essential for the higher education students especially when originated from a different cultural background. The majority of respondents believed that communication, support, and self-confidence are all at high levels (Ismail et al., 2015).

\section{Support}

The results showed that the overall agree percentage is $65.21 \%$, reported that mentoring program increased their support. Regarding the support element the respondents most agreed that "my mentor motivates me to improve my interpersonal communication skills" and "my mentor always gives me positive comments". This method of learning has expanded the level of communication between lecturers and students (mentees), with these approaches successfully transmitting knowledge, skills, and abilities to students (Azman et al., 2007). A more in-depth examination of the mentee mentoring system revealed that the mentoring program's methods can impact the success of mentees, particularly students at higher education institutions (Raelin, 2000; Sambrook, 2001). The implementation of this programs will inspire mentees to acquire new knowledge, skills, and capabilities in order to improve their psychosocial well-being and academic achievement (Oliver \& Aggleto, 2002; Kleinman, Siegel \& Eckstein, 2001). It was discovered that face-to-face communication and open communication are critical components in ensuring the effectiveness the mentee mentoring programs (Bernier et al., 2005; Azman et al., 2007; Ismail \& Ridzwan, 2012).

\section{Self- efficacy}

Students' perceptions toward self-efficacy in mentoring program showed that most of the respondents adapting myself in learning and involving actively in class discussions. The results showed that 9 (19.6\%) disagreed and 37 (80.4\%) agreed that that mentoring program increased their self-efficacy. The item of "I believe that mentoring programs can help me in adapting myself in learning" and item "I am confident that mentoring program may help me in involving actively in class discussions" got the high scoring among the respondents. According to Blanchard \& Thacker (2007), self-reliance is the confidence and ability of the individual to perform a responsibility. People with high self-efficacy often share knowledge, able to deal with problems and constantly improve their performance. But he also says individuals who are not passionate about performing a task, are easy to give up and do not have self confidence in a person who is less self-efficacy. The belief and confidence of the respondent on the implementation of mentee mentoring programmers can enhance academic achievement. It is supported by Ismail et al. (2015) reported that in the organization studied, the mentorship programs is an important predictor of mentees' self-confidence in doing a task.

\section{Psychosocial}

The findings revealed that $91.30 \%$ of respondents agreed that the mentoring programs improved their psychosocial. The item "I am able to meet new students" got the high scoring. Academic achievement among respondents can be increased when good relations with friends, lecturers and staff are established. With a good relationship, the confidence in the ideas can be improved. According to Ljungberg (2011), stated that psychosocial problems can be dealt with through guidance from the mentoring program being executed. It was supported by, Santos and Reigadas (2002), reported that this discovery revealed that a mentor can assist and facilitate a student's personal and academic adaption to college life by 
offering emotional support. In the context of the university, a psychosocial mentee is often defined as a student who is attempting to adapt to the university environment (Dutton, 2003; Santos \& Reigadas, 2005). Although the nature of this relationship is essential, little is known about the mentee's self- and psychological roles as an important component in mentoring models at the university level (Ismail \& Ridzwan, 2012; Santos \& Reigadas, 2005). In higher education institutions, mentoring may also lead to improved psychological development of mentees (Allen \& Finkelstein, 2003; Bernier et al., 2005; Dutton, 2003). It is supported by Ismail et al (2015), reported that the ability of mentors to appropriately implement communication and support in mentorship activities may lead to an enhanced mentees' psychosocial development in the organization.

\section{Academic Performance}

The results of the study show $100 \%$ of the respondents agree that mentoring program increased their academic achievement. Respondents gave high ratings for the items "I am able to perform any responsibility to be a good student". The increase in academic achievement can be proved when the respondent gained good results. The findings shows the respondents it is quite agreed that good academic results can be achieved through the effectiveness of learning methods derived from the mentoring programs. According to Sambrook (2001), the mentee mentor programs is capable of influencing the mentee's, or students', achievement. According to Byrne \& Keefe (2002), the mentor-mentee programs is an excellent strategy for developing an individual's abilities and knowledge. Oliver \& Aggleto (2002) reported that the implementation of the mentoring programs will be encouraged to enable tee to dominate the knowledge, skills and new abilities for the psychosocial improvement and performance of their studies. Studies in university/ faculty mentoring programs reveal that the ability of mentors to appropriately implement such mentoring characteristics may have a significant impact on positive mentee outcomes, especially study performances (Bernier, Larose \& Soucy, 2005; Ismail \& Ridzwan, 2012).

\section{Conclusion}

The results have proven that the implementation of a mentee mentoring program can help in enhancing academic achievement. Through this study, it can indirectly provide knowledge and enhance the existing knowledge to the nursing students. Furthermore, the mentormentee programs can help nursing students improve their academic performance by establishing a more familiar relationship between the nursing tutor and the nursing students. The mentor-mentee programs, on the other hand, might be carried out directly or indirectly by both partners in order to achieve the program's goals. As a result, the influence of mentoring program make the nursing students' daily life is enormous and they will be able to acquire positive actions and attitudes in their daily lives if they are exposed to favorable influences. Mentors will establish positive attitudes and actions in their mentees and will serve as role models for them.

\section{Recommendations}

In the future, research on the mentoring mentee course among nursing students should be expanded by engaging other colleges and including more respondents. As a result, a generalized version of the finding can be obtained. More research should be done by involving more sample studies in order to obtain a more accurate and thorough review findings. Mentorship program should be integrated into the curriculum as a programs that all the allied 
health ILKKM must participate in, with that mentors will receive proper training in order to develop their interpersonal communication skills, use current teaching methods, and encourage students to involved actively in learning. Nurse educators must have a thorough understanding of the mentorship programs. As a result, conferences and seminars for nurse educators to keep up to date on the mentorship programs are required. Future study is needed to assess the impact of a mentorship programs that includes additional universities and includes more participants. As a consequence, a generalized variation of the finding can be obtained.

\section{Acknowledgement}

The researchers would like to thank all of the respondents, as well as the director of ILKKM Kubang Kerian, Kelantan for their cooperation and willingness to volunteer their time.

\section{References}

Allen, T. D., Finkelstein, L. M. (2003). Beyond mentoring: Alternative sources and functions of developmental support. The Career Development Quarterly, 51, 346-355.

Azman, I., Kamsiah, H., Rizal, A. B., Ahmad, R. R. A., \& Junoh, A. M. (2007). Kesan pemindahan pengetahuan, kemahiran dan kebolehan ke atas amalan komunikasi dalam sistem mentoring di institusi pengajian tinggi awam. Jurnal Pendidikan, pp.133-160

Bernier, A., Larose, S., \& Soucy, N. (2005). Academic mentoring in college: The interactive role of student's and mentor's interpersonal dispositions. Research in Higher Education, 46(1), 29-51.

Blanchard, P. N., \& Thacker, J. W. (2007). Effective training: Systems, strategies, and practices ( $3^{\text {rd }}$ ed.). Upper Saddle River, NJ: Pearson Prentice Hall.

Byrne, M. W., Keefe, M. R. (2002). Building research competence in nursing through mentoring. Journal of Nursing Scholarship, 34(4), 391-396.

Chen, C., Liao, J., \& Wen, P. (2014). Why does formal mentoring matter? The mediating role of psychological safety and the moderating role of power distance orientation in the Chinese context. Int. J. Hum. Resour. Manag, 25, 1112-1130.

doi: 10.1080/09585192.2013.816861

Dutton, C. (2003). Mentoring: The contextualization of learning- mentor, protégé and organizational gain in higher education. Education and Training, 45(1), 22-29.

Eller, S. L., Lev, L. E., Feurer, A. (2014) Key components of an effective mentoring relationship: A qualitative study. Nurse Education Today, 32,815-820

Ghosh, R., \& Thomas, G., Reio, Jr. (2013). Career benefit associated with mentoring for mentors: A meta-analysis. Journal of Vocational Behavior, 83,106-116.

Hills, C. W., \& Jones, G. R. (1998). Strategic management: An integrated approach. Boston, MA: Houghton Mifflin Company.

Lee, I. Y., \& Metcalfe, A. (2017). Academic Advisors and Their Diverse Advisees: Towards More Ethical Global Universities. Journal of International Students, 7(4), 944-962. https://doi.org/10.32674/jis.v7i4.183.

Ismail, A., Shariff, M. N., Khian, Jui, M. K., \& Sahol, Hamid, N. (2012). Linking mentoring program to self-efficacy as a predictor of mentee outcomes. International Business Management, 6(2), 131-139.

Ismail, A., \& Ridzuan, A. A. (2012). Relationship between mentoring program and study performance. The mediating effect of self-efficacy. The Proceeding of the 3rd International Conference on Business and Economics Research (ICBER), 12-13 March 2012, Indonesia. 
Ismail, A., \& Jui, K. M. K. (2013). Relationship between Mentoring Program and Mentee Outcomes in Higher Education. The Proceeding of the 1st CHREST International Conference on Labour Market Transformation and Human Resource Development, 8-9 Jan 2013, Kuala Lumpur, Malaysia.

Ismail, A., Abdullah, N. A., Zaidey, N. S. I., Ab Ghani, A., \& Omar, N. (2015). Mentor's role in mentorship as a method of developing mentee's self-confident in performing a task. Jurnal Kemanusiaan, 24(2),1-17.

Ismail, A., Abdullah, N., Ridzwan, A.A., Wan Ibrahim, W.N.A., \& Ismail, Y. (2015). Effect of Mentorship Program on Mentees' Psychosocial Development. International Letters of Social and Humanistic Sciences, 49, 53-65. Retrieved June 3, 2021 from https://www.learntechlib.org/p/176730/.

Ismail, A., Abdullah, N.A., Zaiedy, N.I., Ab Ghani, A., \& Omar, N. (2015). Mentoring Program as an Instrument of Enhancing Mentees' Self Efficacy. Acta Universitatis Danubius,9(1),14-32.

Ismail, A., Abdullah., \& Omar, N. (2016). Amalan Komunikasi Mentor Membangunkan Keyakinan Diri Menti. Jurnal Personalia Pelajar, 19(2), 4957.

Kaye, B. (1997). Up is not the only way. Palo Alto, CA: Consulting Psychologists Press.

Kleinman, G., Siegel, P. H., \& Eckstein, C. (2001). Mentoring and learning: the case of CPA firms. Learning and Organization Development Journal, 22 (1), 22-33.

Ljungberg, I., Kroll, T., Libin, A., \& Gordon, S. (2011). Using peer mentoring for people with spinal cord injury to enhance self-efficacy beliefs and prevent medical complications. Journal of Clinical Nursing, 20, 351-358.

Ljunberg, (2011). Peranan program pementoran dalam meningkatkan kejayaan menti: Kajian empirikal amalan komunikasi di sebuah universiti awam Malaysia. Peranan Program Pementoran Dalam Meningkatkan Kejayaan Menti: Kajian Empirikal Amalan Komunikasi Di Sebuah Universiti Awam Malaysia .

MacGregor, L. (2000). Mentoring: The Australian experience. Career Development International, 5/4/5, 244-249.

Oliver, C., \& Aggleton, P. (2002). Mentoring for professional development in health promotion : A review of issues raised by recent research. Health Education, 102(1), 30-38. doi : 10.1108/09654280210412385

Raelin, A. (2000). Work-based learning: The new frontier of management development. Addison- Wesley, Reading, MA.

Ragins, B. R. (1999). Mentor functions and outcomes: a comparison of men and women in formal and informal mentoring relationship. Journal of Applied Psychological, 84 (4), 29 549.

Rayle, A. D., Kurpius, S. E. R., \& Arredondo, P. (2006). Relationship of self-beliefs, social support, and university comfort with the academic success of freshman college women. J. College Student Retention, 8(3), 325-343.

Rekha, N. K., \& Ganesh, P. M. (2012). Do mentors learn by mentoring others? International Journal of Mentoring and Coaching in Education, 1(3), 205-217

Sambrook, S. (2001). Developing a model of factors influencing work-related learning: Findings from two research projects. EERA Conference on Educational Research. Charles de Gaulle University, September, Lille.

Santos, S. J., \& Reigadas, E. T. (2002). Latinos in higher education: an evaluation of university faculty mentoring program. Journal of Hispanic Higher Education, 1(1), 40-50. 
Santos, S. J., \& Reigadas, E. T. (2005). Understanding the student-faculty mentoring process: Its effect on at-risk university students. Journal of College Student Retention, 6(3), 337357.

Sawari, A. Q., Wahab, M. N. A., \& Aziz, N. A. A. (2016). Evaluation of the characteristics of Interpersonal communication among postgraduate students at a Malaysian public university. Journal of Language and Communication, 3(1), 13-21.

Sulong, A., \& Wan Yusof, W.Z. (2010). Pengaruh Sistem Penasihatan Akademik Terhadap Tahap Pencapaian Akademik Pelajar. Universiti Teknologi Malaysia.

Thacker \& Blanchard. (2007). Peranan program pementoran dalam meningkatkan kejayaan menti: Kajian empirikal amalan komunikasi di sebuah universiti awam Malaysia. Peranan Program Pementoran Dalam Meningkatkan Kejayaan Menti: Kajian Empirikal Amalan Komunikasi Di Sebuah Universiti Awam Malaysia .

Wong, A., Tjosvold, D., \& Lu, J. (2010). Leadership values and learning in China: the mediating role of psychological safety. Asia Pac. J. Hum. Resour, 48, 86-107.

doi: $10.1177 / 1038411109355374$ 